Jurnal Ilmial

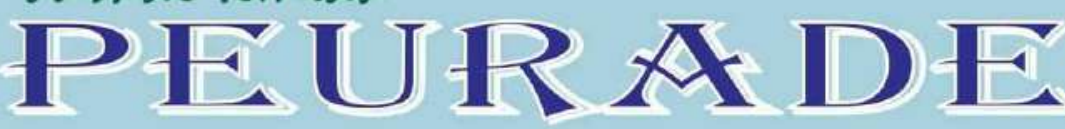

Vol. 5, No. 1, January 2017

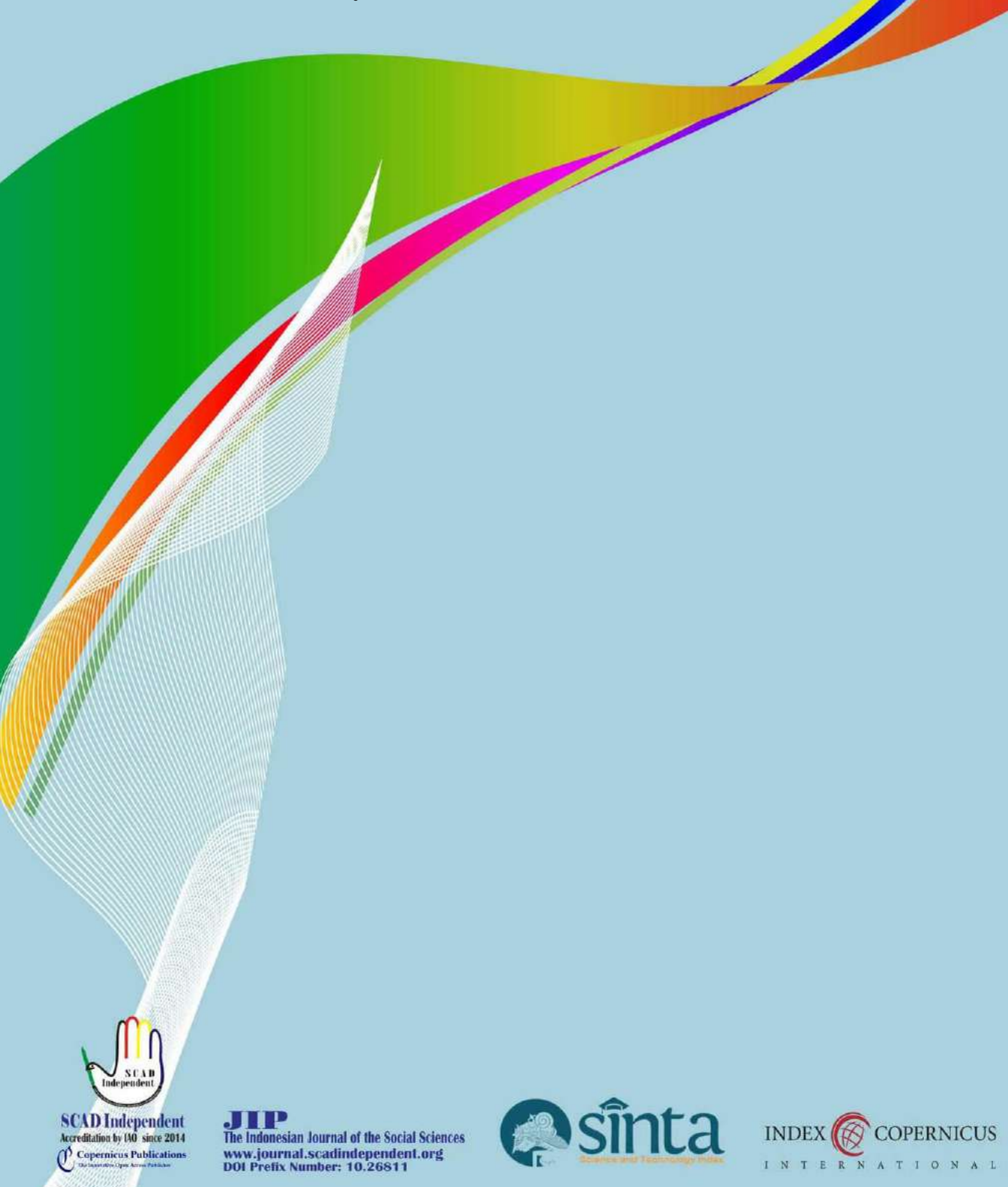




\title{
THE DEVELOPMENT AUTHORITY IMPLEMENTATION OF JUDICIAL REVIEW BY THE CONSTITUTIONAL COURT OF THE REPUBLIC OF INDONESIA
}

\author{
Haposan Siallagan
}

University of HKBP Nommensen Medan, Indonesia

Contibutor Email: haposan.siallagan@yahoo.co.id

Received: Nov 29, 2016

Accepted: Dec 12, 2016

Published: Jan 28, 2017

Article Url: journal.scadindependent.org/index.php/jipeuradeun/article/view/121

\begin{abstract}
All typical products regulated the state could be reviewed and tested through legal actions (legal remedies) facilitated by the constitution of the Republic of Indonesia. This mechanism has known as a review action. In addition, the review on the legislation, related to authorization or the right to review it (toetsingsrecht or the right to review) could be consisted of judges and executives and also the legislatives. The authority of judicial review by the constitutional court is a judicial authority of the constitution. The authorization was a result of the third amendment to the Indonesian constitution of 1945. Regarding the developments of the implementation of the judicial authority by the constitutional court, there were increasing trend of judicial reviews year to year. Thus it indicates the number of regulations have problematic issue in term of of quality. Therefore, it is very urgent to critically evaluate the quality of the formulation of laws in order to avoid the cancellation of the law itself through a judicial authority possessed through the constitutional court.
\end{abstract}

Keywords: Constitutional Court, Judicial Review, Regulations 


\section{A. Introduction}

The dynamics of regulation formation in Indonesia grows rapidly along with the changes of the needs for regulations. Both at the central and at the regional levels, there are many dynamical processes in formatting a regulation each year. Furthermore, the formulation of any regulation itself does not always bear on the legislation entirely, but there are possibilities on revisions of a number of legislation that already exists.

The development of the regulation itself has found the varieties of laws problems that are not synchronized with the regulations at upper level. This condition has ultimately resulted that the government should undertake reform actions to evaluate and reconstruct the legal system formulation in order to maintain the integrity of the hierarchy of legislation itself. Many issues occurred not only in the level of legal products in the level of legislation, but also to the lower levels, such as local regulations.

The most dominant factor that influenced the formulation of the legal product considered the prominence of understanding which situated the regulation as a political product. Indeed, the regulation as a political product has been not debatable. However, considering the forming process, a regulation would be bargaining process of legislative and executive interests through law. As a political product, it may reflect the interests and are not relevant with the constitution. Regarding the principles of hierarchy of law, it should not be against the lower contradictory or not based on the regulation on it (the Constitutional Court, 2016). Nevertheless, the view that as the law is a political product not mean it cannot be argued.

Indeed, the defining of the law as a political product was motivated by the thinking where lawmakers as the authoritative in establishment of legal are mostly representing political. However, the political parties are the ways to represent people. This view, in every step and action were representing the interests of political parties.

Referring back that should (das sollen) legislators need to understand their presence in the legislature people representatives. Unfortunately, this 
crucial issue is not fully applied and understood by most legislators, therefore, there are many ignorance's of people rights, duties and responsibilities. In fact, both the executive and legislative should aware of roles as a representative of the people. In addition, the political interests in the process of establishing a legal product will be minimized.

All typical regulation products as a result of regulation of the state can be reviewed through legal actions (legal remedies) via the Constitution of the Republic of Indonesia. This effort is known as testing (review). Moreover, the review of the regulation, the subject of which is authorized or the right to test it (toetsingsrecht or the right to review) that consisted of judges and executives and also the legislatives. But, if the review initiated by the legislature, then the reviews known the "legislative review". Meanwhile, when the review carried out by executives as a role in the formulation of legislation, then this step is known as "executive review" (Asshiddiqie, 2007: 254).

Furthermore, if the review carried out by judges called "judicial review". Of some review processes, the most frequent and dominant reviews of legislation in Indonesia was through the judicial review. Meanwhile, the other models (executive review and legislative review) are never happened yet. The institutional interest mainly reasons, both legislative and executive are not yet act steps.

\section{B. Judicial Review and Basic Institutionalization}

1. The Definition of Judicial Review and Basic institutionalization

In currently theoretical perspective, the judicial power is one of the pillars of democratic state. Therefore, the judicial authority in Indonesia has significant role. One of the roles of the judicial power itself is to conduct judicial review of regulation. Judicial review is an institutional process which authorizes the court or judicial institution to review through applying or interpreting the provisions and spirit of the constitution so that the results of the review can strengthen the action of government officials (executive) or from other parties (including parliament) (Munir Fuady, 2009: 81). 
Regarding the definition, therefore, could be understood that the power of judicial review is an authority possessed by a judicial court (the Constitutional Court and the Supreme Court) to reconsider or even eliminate or reinforce any action of the executive of or legislative in formulating any legislation product on the higher legal basis.

In historical fact, the application of a judicial system in various countries was highly different. Not all countries have applied judicial review purely in it state system. One of the countries that is not applying is English. But this is understandable that the UK has no written constitution, in addition, the dominant power of the parliament also contributes to unpopularity of judicial review in the UK.

In many countries, the authority of judicial review is under the authority of the Constitutional Court. Even the Constitutional Court becomes the most important element in modern legal system of a country. Importatly, in countries that are undergoing changes, which had previously been in the system of government, with the state authoritarianism to democratic government system. There are some examples of such countries such as South Africa, Albania, Angola, Bosnia and Herzegovina, Bulgaria, Cambodia, Guatemala and others (Abdul Latif, 2009: 16-17).

\section{Judicial Review in Indonesia}

The reformation spirit between 1997 and 1998 has brought significant changes in the life of democracy in Indonesia. Not only in leadership changes, but also on constitutional structure. The fact that prior to the Amendment of the 1945. Constitution, judicial power of the judiciary (judicial) consists only of courts that culminated in the Supreme Court. The existence of the Supreme Court, in accordance with the principle of 'independent of the judiciary' is recognized to be established in the sense that should not be interfered with or influenced of power, in particularly government.

The independent principle of judges are stipulated in the Basic Regulation of Judicial Power and mentioned in the explanation of Article 24 UUD 1945 which confirms that the judicial power should not be 
influenced by power. However, after the third amendment to the 1945 Constitution was passed, the judicial authorities of the Republic of Indonesia have had another superior court out of Supreme Court. Constitutional Court is equal to the Supreme Court. Therefore, there are a growing number of countries that have established the idea of constitutional court rather than only the Supreme Court (Supreme Court).

It can be stated that Indonesia has been the 78th which adopted the idea of establishing an independent Constitutional Court, meanwhile Austria was in 1920, in addition, Italy was in 1947 and Germany was in 1948. The third amendment of the Constitution of 1945, the Constitutional Court has five major authorities, namely: (a) reviewing the regulation constitutionality; (B) taking a decision or authority on any disputes between state institutions under the regulation; (C) taking a decision regarding the opinion of the House of Representatives that the President and / or Vice President has violated any law do not legally qualify as the President and / or Vice President and therefore may be the evident and can therefore be used as an foundation by the General Assembly to dismiss the President and / or Vice-President; (D) deciding the case of disputes over election results, and (e) deciding any cases in regard to the political parties conflicts (Jimly As-Shiddiqie, 2003: 31).

Referring to the basic idea of the Constitutional Court establishment, it was initially intended to provide the authority of judicial review, while the establishment itself can be defined as a consequence of the development of law and of politics in current time. From political perspective, the occurrence of the Constitutional Court seen as part of efforts to provide checks and balances mechanism between each state power (Muchamad Ali Safa'at, et al., 2010: 3).

Beside the Constitutional Court, the Supreme Court is also carrying out a judicial authority, but the regulations are different in term of judicial authority of each institution. The Supreme Court had authority to reviews the regulations under the law against another law, while the Constitutional Court is authorized to review the regulations against the Constitution. Through the authority, then the mechanism of judicial 
review in Indonesia becomes more complex, but it would need to consider moreo initiative judicial authority to be more ideal. Janpatar Simamora (2016: 30) argues that:

"The idea of judicial review synchronization does not mean that the answer to resolving the judicial problems is only by accepting a centralized model of judicial review as the preposition. There MIGHT be another way to take. But by considering the facts mentioned above, it is so reasonable accepting that a centralized model of judicial review would be so much effective to be applied. Then, by considering the performance records on judicial review between MA and MK, it can be sensibly assumed that MK is a way better to execute the whole process of judicial review than the Supreme Court, not to mention the Court's achievements, institutional supports, the quality of the employees, and its institutional integrity as the guardian of constitution and justice".

To explore deeper of the differences judicial authority of the Constitutional Court and the Supreme Court, then it would be necessary to understand the types and hierarchy of legislation applied today as a review objects in the carrying judicial authority. According to the provisions of Article 7 paragraph (1) of Law No. 12 of 2011 on the Establishment of formulating the regulation that the type and hierarchy of legislation in Indonesia are as follows:

a. The Constitution of the Republic of Indonesia Year 1945;

b. The Decree of the People's Consultative Assembly;

c. The Bills / Government Regulation in Lieu of law;

d. The Decree of Government;

e. The Presidential Decree;

f. Provincial Regulation; and

g. Regulation of the Regency / City.

In the second article (2) explained that the legal power of legislation in accordance with the hierarchy as has been mentioned in article (1). Thus, all laws and regulations shall be subject to the laws and regulations above. If eventually found a contradiction of the regulations at the level it, therefore, there would be any reviews in order to provide synchronization and good standards between legislation inferior to legislation that are in it. 
This typical and hierarchy of regulation becomes the object of the judicial authority of the Supreme Court and the Constitutional Court. According to Article 24C point (1) Constitution NRI of 1945 states that the Constitutional Court has its function to review at first and lately decides of the national constitution, the laws against the Constitution, rulings the disputes of the authorities of state institutions that authorities are granted the Constitution, and to decide dissolution of political parties, and to decide any disputes of general election results. The $24 \mathrm{~A}$ point (1) states that the Supreme Court authority is at the appeal, to examine the regulation under regulation that against other regulations, and have other powers provided by law. Thus, it is clear that the object of a judicial authority of both the implementing agencies of judicial power that is within different contexts (Janpatar Simamora, 2013a: 392-393).

Furthermore Janpatar Simamora (2013a: 392-393) explains that the additional of the People's Consultative Assembly Decree into this typical of regulation hierarchy will lead to problems related juridical which body has the authority to undertake a judicial (judicial) of the People's Consultative Assembly Decree. Because, under the provisions of Article 24C point (1) that the judicial authority of the Constitution is stated under the authority of the Constitutional Court. Meanwhile the review against the regulation under the laws of the legislation put under the authority of the Supreme Court as provided for in Article 24A of the 1945 Constitution.

In reviewing further, the substance in Article $24 \mathrm{C}$ point (1), relating to the authority of the Constitutional Court to examine the law against the Constitution reasonably assert it is not possible as soon published of a regulation that degree of hierarchy are level under the Constitution and a notch above the law. This means that the aforementioned article by itself is already decided permanently at the legislative level under the Constitution where the laws or other laws and regulations are considered equivalent to law (Janpatar Simamora, 2013b: 227).

3. Development of Authority Implementation of Judicial Review by the Constitutional Court

Dealing with the implementation of the constitutional authority of the Constitutional Court, in particular the judicial authority lately has 
been established procedural law, both general and specific. The procedural law of the Constitutional Court applies to all the authority possessed by the Constitutional Court. Meanwhile, the law applies only special events specific to each authority possessed (Fajar, 2006: 129).

Previously discussed that the Constitutional Court carries out judicial authority in line with the establishment of the institution in 2003. There have been imporvements of the achievements. The achievement for executing the authority to judicial review at the Constitutional Court have got many positive responses. Since its establishment, each year has found significant development of a judicial case in the Constitutional Court.

To further examination of how the development of implementing the authority of judicial review by the Constitutional Court, it can be seen in some following tables.

Table 1

The Cases Recapitulation of Judicial Review

\begin{tabular}{|lcc|}
\hline No. & Year of Submission & Received Cases \\
\hline 1 & 2003 & 24 \\
\hline $\mathbf{2}$ & 2004 & 27 \\
\hline $\mathbf{3}$ & 2005 & 25 \\
\hline $\mathbf{4}$ & 2006 & 27 \\
\hline $\mathbf{5}$ & 2007 & 30 \\
\hline $\mathbf{6}$ & 2008 & 36 \\
\hline $\mathbf{7}$ & 2010 & 81 \\
\hline $\mathbf{8}$ & 2011 & 86 \\
\hline $\mathbf{9}$ & 2012 & 118 \\
\hline $\mathbf{1 0}$ & 2013 & 109 \\
\hline $\mathbf{1 1}$ & 2014 & 140 \\
\hline $\mathbf{1 2}$ & 2015 & 140 \\
\hline $\mathbf{1 3}$ & 2016 & 106 \\
\hline & Total & $\mathbf{9 4 9}$ \\
\hline
\end{tabular}

Table. 1 illustrates the development of the implementation of the judicial authority based on the number of cases received by the Constitutional Court each year. Of this perspective, it can be seen that in general, there is an increasing number of cases accepted judicial review by 
the Constitutional Court. The fact that judicial review cases are always increase each year. There was a lower case reported in 2005, 2013 and 2016. In 2005, the number of judicial review cases which received stood at 25 cases, while in the previous year, 2004, the numbers of judicial review cases were 27 cases. Therefore, it is found that decreasing number of cases into two of the previous year.

In 2016, the number of cases received for the year reached 106 cases, while in the previous year, in 2015, the cases reached 140 cases. It can be concluded that cases declined from 2015 to the year 2016 of 34 cases. In addition, in last two years mentioned, the case of judicial review was always increasing from year to year.

As an example can be seen in the last few years. In 2010, the Constitutional Court received a case of judicial review as many as 81 cases. Then the following year, i.e. in 2011, the Constitutional Court received as many as 86 cases. In subsequent development, precisely in 2012, an increase in judicial review cases from previous years, reaching 118 cases. Even in 2014, the number of cases received judicial review of the Constitutional Court has reached 140 cases. Likewise in 2015 also reached 140 cases. These statistics show how much progress the implementation of the judicial authority review from the standpoint of the number of cases received always increase from year to year.

In evaluating the development of a judicial case from the point of cases reported, the cases development can be also seen from another perspective, where the number of verdicts of the Constitutional Court. To further understanding, the following table shows statistical handling cases of judicial review in the Constitutional Court based on number of decisions.

Table 2 The Recapitulation of Judicial Cases based on Verdict

\begin{tabular}{|ccc|}
\hline No. & Submission Year & Number of Verdict \\
\hline 1 & 2003 & 4 \\
\hline $\mathbf{2}$ & 2004 & 35 \\
\hline 3 & 2005 & 28 \\
\hline $\mathbf{4}$ & 2006 & 29 \\
\hline
\end{tabular}




\begin{tabular}{|ccc|}
\hline $\mathbf{5}$ & 2007 & 27 \\
\hline $\mathbf{6}$ & 2008 & 34 \\
\hline $\mathbf{7}$ & 2010 & 61 \\
\hline $\mathbf{8}$ & 2011 & 94 \\
\hline $\mathbf{9}$ & 2012 & 97 \\
\hline $\mathbf{1 0}$ & 2013 & 110 \\
\hline $\mathbf{1 1}$ & 2014 & 131 \\
\hline $\mathbf{1 2}$ & 2015 & 157 \\
\hline $\mathbf{1 3}$ & 2016 & 89 \\
\hline & Total & $\mathbf{8 9 6}$ \\
\hline
\end{tabular}

Closely similar to the statistical of judicial review cases from the perspective of cases received, this angle of the amount of the verdict also experienced the similar thing, where there were trend of increasing decision each year. The Constitutional Court decision of judicial review was not increased from the previous years, namely 2005, 2007 and 2016. In 2005, the Constitutional Court issued 28 verdicts, whereas in the previous year in 2004, the number of the verdict reached 35 . That means was, this found a decreasing number during the period of 7 verdicts.

Furthermore, in 2007 the Constitutional Court issued 27 verdicts, while in 2006 the Constitutional Court produced 29 verdicts. Therefore, there was a decreasing number of 2 verdicts. Subsequently in 2016, the Constitutional Court produced 89 cases of judicial review, and in 2015, the number reached 157 decision verdicts.

Among these three perspectives of the development of the implementation of the judicial authority also can be by using the perspective of the number of laws that were reviewed by the Constitutional Court. If this perspective applied, it will be an overview of case reviewing as shown in the following table.

Table 3

The Recapitulation of the Judicial Review bsed on Regulations reviewed

\begin{tabular}{|ccc|}
\hline No. & Submission Year & Number of Reviewed Regulations \\
\hline 1 & 2003 & 16 \\
\hline $\mathbf{2}$ & 2004 & 14 \\
\hline
\end{tabular}




\begin{tabular}{|ccc|}
\hline $\mathbf{3}$ & 2005 & 12 \\
\hline $\mathbf{4}$ & 2006 & 9 \\
\hline $\mathbf{5}$ & 2007 & 12 \\
\hline $\mathbf{6}$ & 2008 & 18 \\
\hline $\mathbf{7}$ & 2010 & 58 \\
\hline $\mathbf{8}$ & 2011 & 55 \\
\hline $\mathbf{9}$ & 2012 & 0 \\
\hline $\mathbf{1 0}$ & 2013 & 64 \\
\hline $\mathbf{1 1}$ & 2014 & 71 \\
\hline $\mathbf{1 2}$ & 2015 & 77 \\
\hline $\mathbf{1 3}$ & 2016 & 72 \\
\hline & Total & $\mathbf{4 7 8}$ \\
\hline
\end{tabular}

In addition of the three perspectives, the progress of implementation of judicial authority can also seen from decision of the Constitutional Court. At this viewpoint applied, the facts can be seen in the following table.

Table 4

The Recapitulation of the Judicial Review based on Verdicts

\begin{tabular}{|cccccc|}
\hline No. & Year & \multicolumn{3}{c|}{ Verdicts } \\
\hline & & Accepted & Rejected & Not Accepted & Withdrew \\
\hline $\mathbf{1}$ & 2003 & 0 & 0 & 3 & 1 \\
\hline $\mathbf{2}$ & 2004 & 11 & 8 & 12 & 4 \\
\hline $\mathbf{3}$ & 2005 & 10 & 14 & 4 & 0 \\
\hline $\mathbf{4}$ & 2006 & 8 & 8 & 11 & 2 \\
\hline $\mathbf{5}$ & 2007 & 4 & 11 & 7 & 5 \\
\hline $\mathbf{6}$ & 2008 & 10 & 12 & 7 & 5 \\
\hline $\mathbf{7}$ & 2010 & 17 & 23 & 16 & 5 \\
\hline $\mathbf{8}$ & 2011 & 21 & 29 & 35 & 9 \\
\hline $\mathbf{9}$ & 2012 & 30 & 31 & 30 & 6 \\
\hline $\mathbf{1 0}$ & 2013 & 22 & 52 & 23 & 13 \\
\hline $\mathbf{1 1}$ & 2014 & 29 & 41 & 43 & 18 \\
\hline $\mathbf{1 2}$ & 2015 & 25 & 50 & 65 & 17 \\
\hline $\mathbf{1 3}$ & 2016 & 17 & 31 & 31 & 10 \\
\hline & Total & $\mathbf{2 0 4}$ & $\mathbf{3 1 0}$ & $\mathbf{2 8 7}$ & $\mathbf{9 5}$ \\
\hline
\end{tabular}


From verdict perspective, it can be elaborated that of the four types of the decisions of the Constitutional Court in the case of judicial review, the verdict is accepted, denied, accepted and withdrawn, the entire verdict is always there every year, except in 2003 that there were no verdicts were granted and rejected and in 2005 there is no verdict was withdrawn.

Based on the verdict, the most significant verdict was rejected stood at 310, then followed of verdict were not accepted of 287 verdicts and with dawn were at 95 verdicts. The cases accepted reached 204 verdicts. Therefore, it can be concluded that there were at least 204 regulations laws have been canceled by the Constitutional Court through the exercise of judicial authority.

It indicates that there are so many regulations that are problematic by the Constitutional Court. If it is equally divided in years since the establishment of the Constitutional Court, there were 15 regulations cancel every year. Thus the numbers certainly indicate that remains many regulations to be evaluated in terms of drafting in legislation level. Moreover, the Constitutional Court will not perform cancellation of any regulations along did not reveal any conflict between legislation that is higher, the State Constitution.

Therefore, the development of power implementation of judicial review by the Constitutional Court has increased each year. Indeed, there should be knowledgeable as a signal to reorganize the quality of the formulating any regulations at legislation. Through such an effort, it is believed that year to year the quality of the regulations would be better to minimize the cancellation due to the quality of legislation drafted by the parliament and the government.

\section{Conclusion}

The development on implementation the judicial authorities of the Constitutional Court, in reviewing any regulation by the Constitution has increases each year. This can be good evidences and standpoints of the number of cases received in the case of judicial review. Therefore, the perspective of the number of regulations reviewed as well as the verdict in 
the case of judicial review itself. The whole perspective has really give picture of how the case of judicial review in the Constitutional Court has increased from year to year.

\section{Bibliography}

Abdul Latif, Fungsi Mahkamah Konstitusi, Upaya Mewujudkan Negara Hukum Demokrasi, Yogyakarta: Total Media, 2009.

Alviandri. (2007). Judicial Review dalam Ketatanegaraan Indonesia, Program Pascasarjana Ilmu Hukum Universitas Muhammadiyah, Surakarta.

Amrullah, A. (2014). Paradigma Saksi Mahkota dalam Persidangan Pidana di Indonesia. Jurnal Ilmiah Peuradeun, 2(2), 83-104.

Asshiddiqie, Jimly. (2003). "Struktur Ketatanegaraan Indonesia Setelah Perubahan Keempat UUD Tahun 1945", Makalah dalam Seminar Pembangunan Hukum Nasional VIII yang diselenggarakan oleh Badan Pembinaan Hukum Nasional, Departemen Kehakiman dan HAM RI, Denpasar, 14-18 Juli 2003.

Asshiddiqie, Jimly. (2007). Pokok-Pokok Hukum Tata Negara Indonesia Pasca Reformasi, Jakarta: Bhuana Ilmu Populer, 2007.

Fadjar, Abdul Mukthie (2006)., Hukum Konstitusi dan Mahkamah Konstitusi, Jakarta: Konstitusi Press dan Citra Media, Yogyakarta.

Fuady, Munir. (2009). Teori Negara Hukum Modern, Rechtstaat, Jakarta: Refika Aditama.

Gustavo Femandes de Andrade (2001). “Comparative Constitutional Law: Judicial Review, Journal of Constitutional Law, Vol. 3:3, May 2001.

Kelsen, Hans (1973), General Theory Of Law, Translated by Andrew Wedberg, Russel\&Russel, New York, sebagaimana dikutip Elviandri dari Sumali, Reduksi Kekusaan Eksekutif Di Bidang Peraturan Pengganti UndangUndang (PERPU), Malang: UMM Press, 2002.

Lvina, E. (2015). The Role of Cross-Cultural Communication Competence: Effective Transformational Leadership Across Cultures. Jurnal Ilmiah Peuradeun, 3(1), 1-18.

Mahkamah Konstitusi. (2016). Sejarah dan Pembentukan, Kedudukan serta Kewenangan 
MahkamahKonstitusi,http://www.mahkamahkonstitusi.go.id/index. php?page=web.Berita\&id=11768\#.WDLPS9KLTIU, diakses pada 20 November 2016.

Morgan, J. H. (2014). Americanizing Islam as the Price of Assimilation. Jurnal Ilmiah Peuradeun, 2(2), 1-16.

Safa'at, Muchamad Ali, dkk. (2010). Hukum Acara Mahkamah Konstitusi, Jakarta: Sekretariat Jenderal dan Kepaniteraan Mahkamah Konstitusi.

Simamora, Janpatar. (2006). “Considering Centralization Of Judicial Review Authority In Indonesia Constitutional System", IOSR Journal of Humanities And Social Science (IOSR-JHSS), Shastri Nagar, Ghaziabad: International Organization of Scientific Research, Vol. 21, Issue 2, Ver. V Feb. 2016.

Simamora, Janpatar. (2013a). Problem Yuridis Keberadaan TAP MPR dalam Hierarki Peraturan Perundang-undangan Menurut Undang-Undang Nomor 12 Tahun 2011, Jurnal Legislasi Indonesia, vol. 10 No. 3 September 2013, Jakarta: Direktorat Jenderal Peraturan Perundangundangan Kementerian Hukum dan HAM RI.

Simamora, Janpatar. (2013b). “Analisis Yuridis Terhadap Model Kewenangan Judicial Review di Indonesia", Jurnal Mimbar Hukum, Vol. 25 No. 3 Oktober 2013, Yogyakarta: Fakultas Hukum Universitas Gadjah Mada.

Tabrani. ZA. (2014). Islamic Studies dalam Pendekatan Multidisipliner (Suatu Kajian Gradual Menuju Paradigma Global). Jurnal Ilmiah Peuradeun, 2(2), 127-144.

Tabrani. ZA. (2016). Perubahan Ideologi Keislaman Turki (Analisis GeoKultur Islam dan Politik Pada Kerajaan Turki Usmani). Jurnal Edukasi: Jurnal Bimbingan Konseling, 2(2), 130-146.

Wardron, Jeremy, (2016) "The Core of the Case Against Judicial Review", The Yale Law Journal, Vol. 115, 2006. 